\title{
Network heterogeneity and seizure generation
}

\author{
Sima Mofakham ${ }^{1 *}$, Christian G Fink ${ }^{2}$, Victoria Booth ${ }^{3}$, Michal R Zochowski ${ }^{1,4,5}$ \\ From 24th Annual Computational Neuroscience Meeting: CNS*2015 \\ Prague, Czech Republic. 18-23 July 2015
}

It has been shown that seizures occur more frequently at the transition from wake to sleep, or from one stage of sleep to another. Acetylcholine (ACh) is a neuromodulator that controls wake and sleep stages, and is present at high levels during waking and is absent in slow wave sleep (SWS). ACh has also been shown to switch the excitability as measured with Phase response curves (PRC) of pyramidal cells from Type 2 to Type 1 . In general, Type 1 neurons are integrating type with highexcitability while Type 2 have lower excitability but higher capacity for synchronization. We investigate the effect of non-uniform cholinergic modulation, such as might occur at sleep/wake transitions, on the propensity for neuronal synchronization in large-scale networks of Hodgkin-Huxley models for cortical pyramidal cells. The interplay between the cellular properties and network connectivity in a heterogeneous network of Type 1 and Type 2 neurons can strongly affect network spatiotemporal dynamics. The focus of this research is to detect conditions that promote synchrony and seizure like activity in a mixed network of Type 1 and Type 2 neurons. Here we investigate inhomogeneous networks built of neurons that have non-identical connectivity properties. Namely every cell has an individual ratio of local and long distance synaptic connections. We show that even if the structure of the network is identical (i.e. identical adjacency matrix) there is a differential network-wide synchronization propensity depending on which neurons have Type II cellular properties.

\footnotetext{
Authors' details

'Biophysics program, University of Michigan, Ann Arbor, MI , USA.

${ }^{2}$ Department of Physics \& Astronomy and Neuroscience Program, Ohio Wesleyan University, Delaware, OH, USA. ${ }^{3}$ Departments of Mathematics and Anesthesiology, University of Michigan, Ann Arbor, MI, USA. ${ }^{4}$ Department of Physics, University of Michigan, Ann Arbor, MI, USA. ${ }^{5}$ The R.B. Zajonc Institute for Social Studies, Stawki, Warsaw, Poland.
}

* Correspondence: mofakham@umich.edu

${ }^{1}$ Biophysics program, University of Michigan, Ann Arbor, MI , USA

Full list of author information is available at the end of the article
Published: 18 December 2015

doi:10.1186/1471-2202-16-S1-P302

Cite this article as: Mofakham et al:: Network heterogeneity and seizure generation. BMC Neuroscience 2015 16(Suppl 1):P302.
Submit your next manuscript to BioMed Central and take full advantage of:

- Convenient online submission

- Thorough peer review

- No space constraints or color figure charges

- Immediate publication on acceptance

- Inclusion in PubMed, CAS, Scopus and Google Scholar

- Research which is freely available for redistribution

Submit your manuscript at www.biomedcentral.com/submit

\section{Biomed Central}

C Biomed Central

(c) 2015 Mofakham et al. This is an Open Access article distributed under the terms of the Creative Commons Attribution License (http://creativecommons.org/licenses/by/4.0), which permits unrestricted use, distribution, and reproduction in any medium, provided the original work is properly cited. The Creative Commons Public Domain Dedication waiver (http://creativecommons.org/ publicdomain/zero/1.0/) applies to the data made available in this article, unless otherwise stated. 